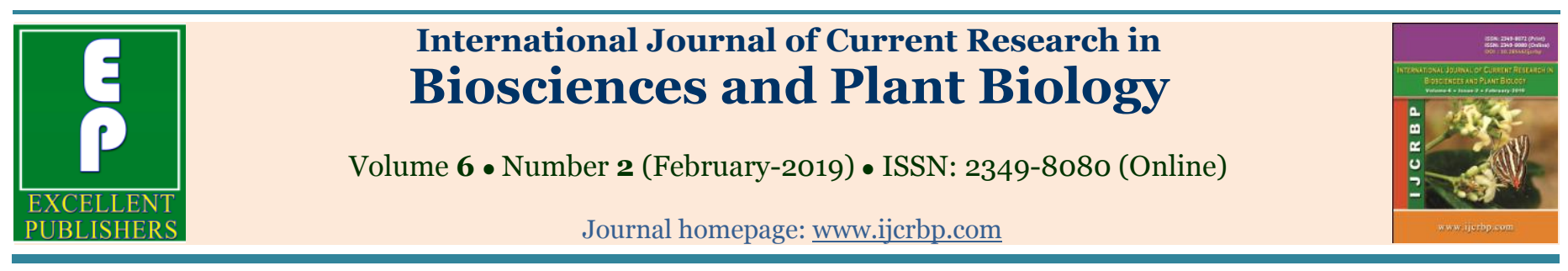

\title{
Determinism of shade off in tropical species of the Sudano - Sahelian zone of Cameroon
}

\author{
J. B. N. Nduryang1, Y. Hamawa ${ }^{1,2}$, C. Baye-Niwah1,2, R. Tsobou ${ }^{1,3}$, \\ G. Fawa ${ }^{1}$ and P. M. Mapongmetsem ${ }^{1 *}$
}

${ }^{1}$ Laboratory of Biodiversity and Sustainable Developpment, Faculty of Sciences, University of Ngaoundere, P.O.Box 454 Ngaoundere, Cameroon

${ }^{2}$ High Teaching School, University of Maroua P.O.Box 46 Maroua, Cameroon

3Polytechnique School, University of Maroua P.O.Box 46 Maroua, Cameroon

4Faculty of Science, University of Dschang P.O.Box 67 Dschang, Cameroon

${ }^{*}$ Corresponding author; e-mail: piermapong@yahoo.fr

\begin{tabular}{|c|c|}
\hline Arti & \multirow{5}{*}{$\begin{array}{l}\text { ABSTRACT } \\
\text { Phenological studies were undertaken on ten indigenous species of socio - economic } \\
\text { importance of the Sudano-Sahelian zone of Cameroon. The selected species were } \\
\text { Adansonia digitata L., Balanites aegptiaca (L.) Del., Detarium microcarpum Guill. \& } \\
\text { Perr., Diospyros mespiliformis Hochst. ex A. Rich., Haematostaphis barteri Hook. f., } \\
\text { Hexalobus monopetalus (A. Rich.) Engl. \& Diels, Parkia biglobosa (Jacq.) R. Br. ex G. } \\
\text { Don, Sclerocarya birrea (A. Rich.) Hochst., Tamarindus indica L. and Vitex doniana } \\
\text { Sweet. The studies which involve monitoring of the selected species were carried out } \\
\text { from } 2015 \text { to } 2017 \text { along isoyets in the Sudano-Sahelian zone of Cameroon. The main } \\
\text { objective of the study was to assess the phenological behaviour of the selected species in } \\
\text { their natural habitat, with a view to determining their response to climate change in } \\
\text { terms of shading off. If we understand sufficiently about it, and have at least a basic } \\
\text { understanding of phenological characteritics, morphological and physiological } \\
\text { adaptative behaviour when exposed to environmental change, we will be able to } \\
\text { propose appropriate management techniques to optimize the product we required. The } \\
\text { results reveal significant differences between species (o.oooo < o.oo1), years (o.o1 } \\
\text { o.o5) and isoyets (o.o1 < o.o5) concerning mean period of defoliation. For the range of } \\
\text { defoliation, significant differences exit equally between species (o.oooo<o.oo1), years } \\
\text { (o.ooo2<o.oo1) and isoyets (o.ooo2<o.oo1). Two categories of species are } \\
\text { distinguished : deciduous and evergreen. The range of defoliation among species is } \\
\text { equally significanly different (o.oooo < o.oo1). Clamatic data in relation with } \\
\text { phenological manifestations show that even if it is possible to find mean patterns, } \\
\text { individual factors remain very important for more refined predictions, before more } \\
\text { quantitative explorations, which must be foreseen, are done. These informations are } \\
\text { important in the elaboration of efficient domestication strategies }\end{array}$} \\
\hline & \\
\hline & \\
\hline Keywords & \\
\hline $\begin{array}{l}\text { Cameroon } \\
\text { Climate } \\
\text { Defoliation } \\
\text { Domestication } \\
\text { Socio-economic sp } \\
\text { Sudano-Sahelian }\end{array}$ & \\
\hline
\end{tabular}




\section{Introduction}

In the Sudano-Sahelian zone of Cameroon, socioeconomic local plant species occupy an important place in the rural communities and in the food security of the housholds (Tchiégang-Megueni et al., 2001; Gautier et al., 2002; Eyog et al., 2006; Mapongmetsem et al., 2012). Unfortunatelly, in locality of high population growth where agriculture and breeding remain the main socioeconomic activity, they assist to overexploitation of natural resources resulting to the reduction of vegetal cover of the environment (Gormo, 2013). Therefore the problematique of sustainable management of soils in a bit to occur to food needs of the population as well as maintening long terms productivity remain up to date (Traoré, 2000; Mapongmetsem et al., 2010). This alarmant situation leaded to search efficient strategies against this calamity. These strategics options have consisted to redymise and modernise agroforestry systems and reafforest denuded zones (Mapongmetsem et al., 1999; Lebel et al., 2002; Traoré, 2000). Despite these different humen and financial efforts, problems still persit (Baumer, 1987). Gentic resources management and conservation must pass trough a reintrocuction of suitable species to different production ecosystems among which agroforestry systems in view to durably participate to socio-economically development of the local comunities (Diallo et al., 2015; Mapongmetsem et al., 2010). The first step of the domestication process of these plant species of great importance is to master mecanism of defoliation and to know the exact period of litterfall in the zone. Very few studies were devoted to plant phenology and few species were studied in the tropics. To the best of our knowleges, little attention has been focused on this aspect except the works of Mapongmetsem (2005) and Mapongmetsem et al.(1998). The assessment of plant phenology permits to know the auto-ecology of a species in order to select the suitable genotype for the futur reafforestation in different contexts for those of origin (Abdallah et al., 1999). The master of the auto-ecology of plant species constitutes an essential step in the process of the rational management of ecosystems, and particularly the explotation of local plant species. Defoliation of plant trees covers a capital importance in the restitution of part of phytomasse in terms of litters which increases the rate of organic matter in the soil. Litter decomposition releases in the soil biogenic compounds which are useful to plants (Puig \& Delobelle, 1988; Mapongmetsem, 2005; Diallo et al., 2016).

The main objective of the work is to evaluate defoliation modalities in order to determine mean periods and ranges of leave shade off. Two hypothesis were formulated: a) the development sequence of this phenophasis could vary from one species to another as well as from individual to another; and from year to another; b) it could also vary according pedoclimatic conditions of the site.

\section{Materials and methods}

\section{Study site}

The work was carried out in the Sudano-sahelian zone of Cameroon, grouping nothern and Far north regions. In the south of the Benue Divion (from April to October), the rainy season duration is 7 months but in the Chari, it lasts 3 months (from June to August) (M'biandoun et al., 2003). Based on the distribution of precipitations in the zone, five isoyets (lines along which the rainfall is constant) selected were : $1=600-700 ; 2=700-$ $800 ; 3=800-900 ; 4=900-1000 ; 5=1000-1100$ $\mathrm{mm}$ (Fig.1). Each isoyet is represented by three phenological stations. Waza, Bogo and Maga belong to 600-700mm; Maroua, Salak and Moutourwa to 700-800mm; Kaélé, Touloum and Dziguilao to 800-900mm; Bidzar, Guider and Louggéré to 900-1000 $\mathrm{mm}$ and Dourbeye, Mayooulo and Peské-bori to 1000-1100mm. Phenological stations are equidistant among themselves for about $10 \mathrm{~km}$. Previous studies in the area demonstrated that the following species (Adansonia digitata, Balanites aegptiaca, Detarium microcarpum, Diospyros mespiliformis, Haematostaphis barteri, Hexalobus monopetalus, Parkia biglobosa, Sclerocarya birrea, Tamarindus indica and Vitex doniana) are among those of a great socio-economic importance for the local population (Mapongmetsem et al., 2012). They provide numerous products and services to farmers (medicaments, foods, fodders, fuelwoods, shade, construction materials, etc.). They represent important source of income for the local comunities (Fawa et al., 2015; Mapongmetsem et al., 2008; Mapongmetsem et al., 2012; Mapongmetsem et al., 2015). Despite their socio economic importance, they are still in wild live and 
subjected to zoo-anthropic presures. All the ten plant species were present in each station. Each plant species was represented by 10 adult trees in perfect sanity status and each labelled.

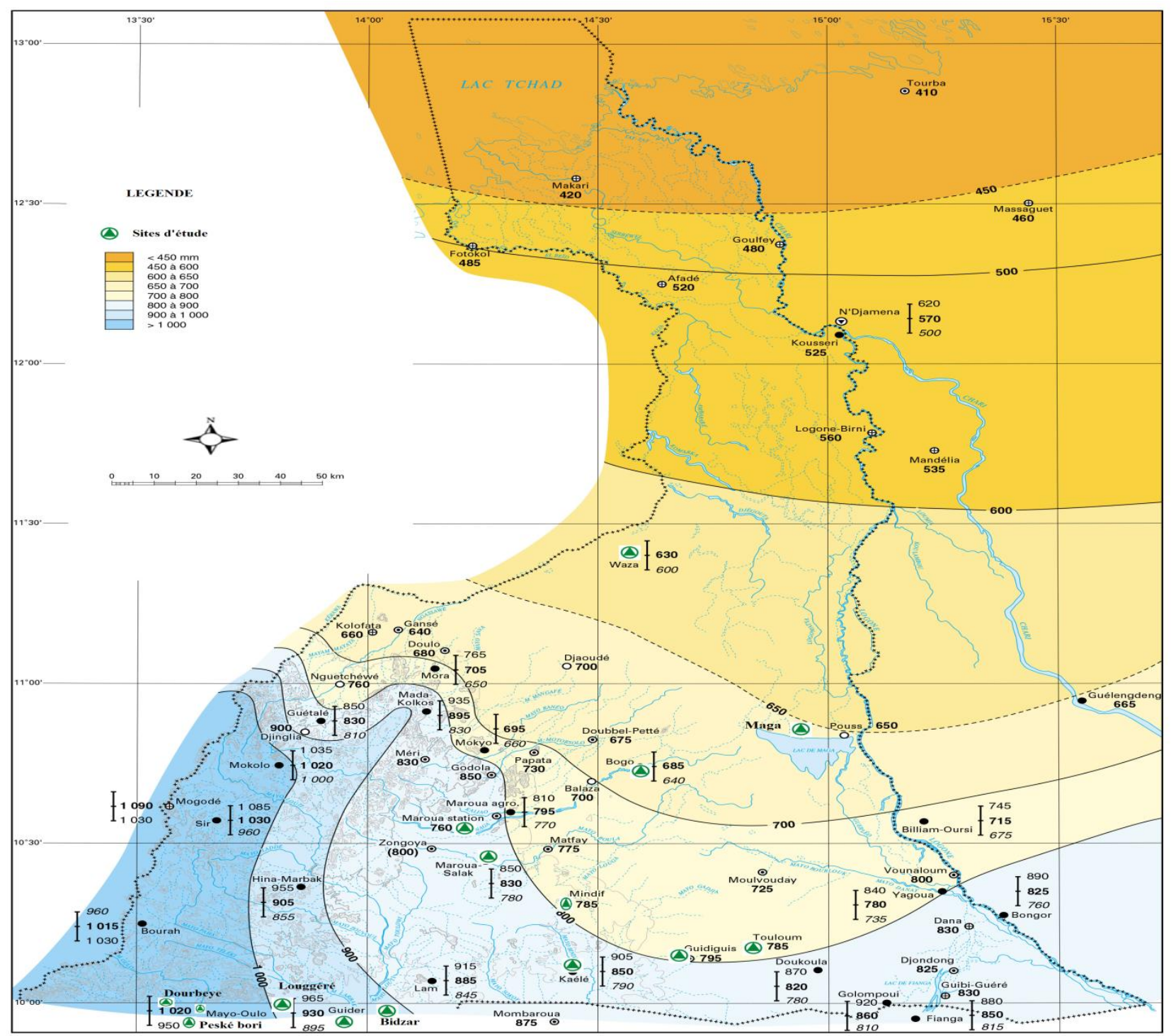

Fig. 1: Localisation of study sites. Source : IRD (2000) $D B=$ Dourbeye, $M O=$ Mayo-oulo, $P B=$ Peské-bori, LG = Louggéré, $\mathrm{GD}=$ Guider, MT = Moutourwa.

\section{Methodology}

Phenological observations were undertaken in each station on the aforementioned species from January 2015 to December 2017 in a monthly basis. The phenological calender was coded as it follows: January $=1$, February $=2$, March $=3, \ldots$. November = 11 and December = 12 (Mapongmetsem, 1994; Mapongmetsem et al., 1998). Characterisation of the defoliation was based on the methodology of Kouyaté (2005) and Mapongmetsem (1994). The experimental design was a split-split-plot with three replications. The treatments was represented by plant species, the sub-treatment was isoyet whereas the sub-sub-treatment was the year. Phenological station corresponded to repetitions. The experimental unit was made up of 10 trees. Thus the total number of trees managed was $10 \times 10 \times 5 \times 3=$ 5300 individuals. Data collected were subjected to analysis of variance. Comparison of the significant mean was done through Duncan Multiple Range Test (DMRT) whereas their separation used LSD at 5\%. The statistical programme used was Statgraphics plus. 


\section{Results and discussion}

The In the Sudano-sahalian zone of Cameroon, the phenological behaviour of the selected species exhibits rougthly intraspecific and interspecific variations among them.

\section{Intraspecific variations}

The yellowing of leaves and litter fall in Adansonia digitata started at the end of October and the apogee is achieved in January. The tree is deciduous. The period of naked branches stays between 3 to four months. In some individuals, leaves shade off lasts a month. According years, individuals present disparities among themselves going from partial to total defoliation. In humid lowlands of Cameroon, such pattern was reported in forest species (Mapongmetsem et al., 1998). The authors reported that each tree has its internal watch. It is not scare to see that in the same station, two individuals near by near present the same type of comportment confirming the conclusion of the authors. This result agrees the fact that each individual tree is a specific case. The maximum of trees which shaded their leaves was in February (89.28\%) (2015), January 2016 (65\%) and February 2017 (87.85\%).

Concerning isoyet, the analogous pattern was observed. The peak of of trees defoliated was registered in the isoyet $3(86.67 \%)$ whereas $83.33 \%$; 83.33 and $78.33 \%$ were noted respectively in isoyet 4, 5, 2 and 1. Similar results was reported in northern Senegal (Poupon, 1980).

Balanites aegyptiaca is an evergreen species. In this species, old leaves fall without special rythm, then are simultaneously replaced with new one. Of cause the species keeps its leaves all over the year but nevertheless during dry season ligthening foliaceous is observed. Individual variations of partial defoliation are noted.

Yellowing and leaves shade off in Detarium microcarpum start in December and end in March. There is absence of homogeneity in defoliation among individuals. Some individuals are deciduous stage in February while other in March. In other trees, there is partial defoliation which goes along with refoliation. The most important percentage of trees defoliated were registered in March (73.33\%) in the isohyet 2; 66.66\% in isohyet $3 ; 64.44 \%$ in isohyet $4 ; 61.11 \%$ in 5 . Similar results were reported in Mali (Kouyaté, 2005). According to the author, Detarium microcarpum drops its leaves during the dry season in Mali. Grouzis \& Sicot (1980) argue that simultaneous diminution of air relative humidity and soil hydric reserve can justify leaves shade off in sahelian zone of Africa. Others think that phenology of tropical trees varies according to environmental seasonality conditions, essentially precipitations (Reich et Borchert, 1984; Newberry et al., 2006). Devineau (1999) classes Detarium microcarpum among species with little phenological plasticity. It presents adapatative advantages due to reccurent pertubations such as bush fires (Bastide et Ouédraogo, 2009).

Concerning the years, interannual disparities have been registered. Maximum defoliation $(80.90 \%$ of trees defoliated) was observed in 2015 et 2016. However, in the year 2017, the percentage of trees defoliated was generaly very low (37.27\%).

Diospyros mespiliformis like Balanites aegyptiaca keeps its leaves all over the year. It is reported as evergreen one (Mahamane et al., 2007). Old leaves drop from January to May followed immediatelly by flushing and flowering. There is lack of rythmicity in defoliation phenophasis in this species. This defoliation takes place in cold dry season.

Partial defoliation is noted in Haematostaphis barteri between Novembre and April for 98\% of leaves dropped. Total defoliation has not been observed. Leaves become yellow and turned to reddish and drop from the tree without a synchronous rythm. Individual variations suggested that trees resistance to drough keep their leaves for a long time. Analogous results have been reported in the Guinean Savannah Higlands of Cameroon in Ximenia americana (Mapongmetsem, 2005). The zenith of defoliation was observed in January $(100 \%$ of trees was defoliated). The same behaviour was registered all over the three years.

Concerning isohyet, the rate of defoliated trees oscillate between $15.55 \%$ in February and 92,22\% in March in isoyet 2. It varies from $18.88 \%$ to $97.77 \%$ in isohyet 3 ; from $13.33 \%$ to $88.88 \%$ in isohyet 4 ; from $13.33 \%$ to $86.66 \%$ in isohyet 5 . 
Interannual variation has been registered too. Maximum tree defoliation is situated in March 2016 (99.16\%); 2017 (87.5\%) and 2015 (86.66\%).

In Parkia biglobosa two phenomenons were observed: lightening foliaceaous and partial defoliation. Its last were observed from November to February. Partial defoliation is gradual and occurs in cold dry season indicating that relative humidity influences leaves drop. Sanogo (1997) showed in Mali that some savannah species among which Diospyros mespiliformis, Prosopis africana and Tamarindus indica do not drop their leaves after rainy season. This result suggests that those species develop physiological adapdatives mecanisms which support abcission conditions in cold dry season (Kouyaté, 2005).

Defoliation in Sclerocarya birrea occurs between October and March. This result corroborates that of Zida (2009) in Burkina Faso. It is frequent to observe two individuals in the spot showing a defoliated tree near by another cover with leaves. This pattern confirms the existing of endogenous factor (internal watch among trees of the same species). Genetic factors can explain the individual behaviour in a species. In some individuals, defoliation starts in old branches whereas in others, it beguins from the sommit to the bottom of branches and in others, it is at random or scattered in the canopy of the tree. Young branches loss their leaves in the last position compare to old one. Defoliation is total in some trees while partial in others despite the fact that the species is deciduous.There is asynchronous defoliation in Sclerocarya birrea. The same trend is observed in Ceiba pentandra, Erythrophleum suaveolens and $E$. africanum. Defoliation in those species varies from tree to another and from branch to another in the same tree (Childes, 1988; Richer, 2008; Kouadio, 2009; Mapongmetsem et al., 1998).

The most important pics of defoliation were registered in February 2015 (84.66 \%) and 2016 (74 \%). For isoyet, important variations were registered among them. The most important pic was observed in isoyet 3(92.22\%).

The total leaves dropped in Tamarindus indica trees beguins from March to April while the renewal of leaves is in the same period. There is no temporal separation beween defoliation an flushing in the species. These results are analogous with thoses of Bourou (2012) who noticed that defoliation last 2.5 months in Niokhoul (Senegal). Defoliation in the species is partial and asynchronous among individuals, even in the same tree. Partial one can ocur till 50\% during dry season (El-Siddig et al., 2006). These authors qualify the species as semi-evergreen one. However, Bourou (2012) reported the registration of Tamarindus indica individuals presenting a total defoliation with a short deciduous period. The author explains this phenological behaviour by the response of the species to hydric stress. The fact that plants maintain the hydric potential low participate to strategies to avoid deshydratation (Logan et al., 2011). It is a main physiological mecanism in $T$. indica to be adapted to hydric stress.

Defoliation in Vitex doniana oscillates between Novembre and February. Individuals in different biological stages were registered and very offen in the same individual. Neverthess, total defoliation was not observed. There is lack of synchronism in defoliation in Vitex doniana. It is a caducifoliaceous species (Mapongmetsem, 2005). According to isoyet, major variations were observed. In isoyet 2, the rate of trees defoliated varies from $6.66 \%$ in March to $86.66 \%$ in November. It oscillates between $21.11 \%$ and $72.22 \%$ in isohyet $3 ; 10 \%$ to $65.55 \%$ in $4,21.11 \%$ and $60 \%$ in 5 . Interannual variations were registered with a pic of $75.83 \%$ in Juin 2015. This variation is manifested by the existance of individuals at different biological stages and often in the same tree in the same period. Going in the same way, Fétéké et al.(2016) argue that defoliation in Entandrophragma cylindricum varies from tree to another in Central Africa.

\section{Interspecific variations}

The determinism of defoliation among the plant species can be characterized by the mean period and duration.

\section{Defoliation mean period}

It stands out from table 1 that the mean period of defoliation varies from $2.54 \pm 0,26$ in $D$. microcarpum to $10.22 \pm 0,84$ in $V$. doniana. This indicates that the maximum of trees in $D$. microcarpum shade off their leaves in March 
whereas those of $V$. doniana did it in November. The analysis of variance shows a significant difference among the species (0.0000 < 0.001). The Duncan Multiple Range Test gathers plant species in four groups according to their mean period of defoliation : species that shade off their leaves early in Martch (D. microcarpum); plant species which drop theirs at the beguining of April (S. birrea, Hexalobus monopetelatus); plant species which drop their leaves in mid April (Adansonia digitata, Haematostaphis barteri) and plant species which loss their leaves late in November ( $V$. doniana). The defoliation spectrum is characterised by species that loss leaves early in mid March and those which shade off theirs late in mi-November. Between these extrems, exist intermediary species. Similar pattern has been described in humid lowlands of Cameroon (Mapongmetsem, 1994). In this work Balanites aegyptiaca, Diospyros mespiliformis and Tamarindus indica did not shade off their leaves consequently, they are evergreen. The behaviour of $P$. biglobosa is contradictory to that which was exhibited in the Guinean Savannah Highlands of Cameroon. In the Guinean savannah highlands, $P$. biglobosa showed total defoliation conducted by a long deciduous period (Mapongmetsem, 2005). This contradictory behaviour among these agroecological zones demonstrates that many factors controle the phenodynamism of each species; by this way, confirming our hypothesis concerning pedoclimatic conditions of the site.

According to isohyets, the average period of defoliation varies from $2.37 \pm 1.91$ in isoyet 1 to 2.88 \pm 3.08 in isohyet 5 . The analysis of variance indicates a significant difference among the mean periods of defoliation $(0.01<0.05)$. This result suggested that the mean period of defoliation is influenced by precipitations. The classification based on Duncan Multiple Range Test show 2 groups. The first group is composed of the following isohyets : $3(800-900 \mathrm{~mm}), 4(900-1000 \mathrm{~mm}), 5$ $(1000-1100 \mathrm{~mm})$. The second is made of isoyet 2 (700-800mm) and $1(600-700 \mathrm{~mm})$. This result suggests that defoliation is early in isoyet where precipitation is abondant whereas late for those where rainfall is low. In each group of isohyets the mean date of defoliation is homogeneous.

For the effect of year, the mean period of defoliation ranges from 2.57 in 2015 to 2.82 in
2016. This result indicates that the average period of defoliation varies from year to year. The analysis of variance shows a significant difference between years $(0.01<0.05)$, confirming that plant species do not drop leaves at the same time during year. In the present study, the pic of defoliation in 2015 was in mid March whereas in 2016, it was at the end of March. According to the Duncan Multiple Range Test, two categories of years were distinguished : the first group is constituted by 2015 (2.57) and 2017 (2.70) during which the defoliation date was identical; the second by 2016 (2.82). The mean period of defoliation was earlier (mid March) in 2015 and 2017 whereas in 2016, it was late (end of March).

\section{Defoliation mean range}

Concerning the average duration of defoliation, it appears that, it oscillates from $1.34 \pm 0.33$ in Vitex doniana and $4.66 \pm 0.26$ months in Haematostaphis barteri (Table 1). There is a significant difference between species (0.00o < o.001). It indicates that the duration of defoliation differs between species. This result militates in favor of the existance of endogenous factors which govern defoliation in tropics. A fine analysis with Duncan Multiple Range Test classifies plant following their mean defoliation duration in 5 groups. The extreme are made up of species like Haematostaphis barteri $(4.66 \pm 0.26)$ which spread its defoliation for more than 4 months, then species with massive defoliation (1.5month) such as Detarium microcarpum $(1.28 \pm 1.54)$ and Vitex doniana (1.34 \pm 0.33) (Table 1). Between the two extrems, exist intermediaries species such as $A$. digita, $H$. monopetalus and $S$. birrea.

During dry season, species like Balanites aegyptiaca, Diospyros mespiliformis, Parkia biglobosa and Tamarindus indica drop their leaves wihout showing a deciduous period. Their exhibit sempervirent characteristics in the sudano - sahelian zone of Cameroon. They loss their leaves while at the same time, they recover them. There is lack of synchronous rythm in dropping leaves. Keeping leaves during dry season is an important behaviour that the leaves protect soil against heavy weather.

According to isohyets, the mean defoliation period oscillates between $2.37 \pm 1.91$ in Isoyet 600- 
$700 \mathrm{~mm}$ to $2.88 \pm 3.08$ in Isoyet $1000-1100 \mathrm{~mm}$. Two categories of isoyets were distinguished among which early (Mid-March) and late (end March) defoliation. Defoliation is early in low precipitation isoyet. For the mean defoliation duration varies from $1.40 \pm 1.59$ in isohyet $700-$ $800 \mathrm{~mm}$ to $1.55 \pm 1.62$ month in $800-900 \mathrm{~mm}$
(Table 2). Despite the slight variation observed among isohyets, there is a significant difference between them in terms of defoliation range (0.0002<0.001). The lack of of great difference between isohyets confirms the fact that endogenous manifestations are the main factors which controle defoliation.

Table 1. Mean defoliation variation period and range of species.

\begin{tabular}{lll}
\hline Species & $\begin{array}{l}\text { Mean period of defoliation } \\
\text { (months) }\end{array}$ & $\begin{array}{l}\text { Mean range of defoliation } \\
\text { (months) }\end{array}$ \\
\hline Vitex doniana & $10.22 \pm 0.84 \mathrm{a}$ & $1.34 \pm 0.33 \mathrm{e}$ \\
Adansonia digitata & $4.26 \pm 1.25 \mathrm{~b}$ & $3.2 \pm 1.16 \mathrm{~b}$ \\
Haematostaphis barteri & $4.02 \pm 0.34 \mathrm{~b}$ & $4.66 \pm 0.26 \mathrm{a}$ \\
Hexalobus monopetalus & $3.14 \pm 0.18 \mathrm{c}$ & $1.8 \pm 0.33 \mathrm{~d}$ \\
Sclerocarya birrea & $2.96 \pm 1.23 \mathrm{c}$ & $2.37 \pm 0.87 \mathrm{c}$ \\
Detarium microcarpum & $2,54 \pm 0,26 \mathrm{~d}$ & $1,28 \pm 1,54 \mathrm{e}$ \\
Average & $\mathbf{4 . 5 2} \pm 0.82$ & $\mathbf{1 . 4 8} \pm 0.90$ \\
\hline Means followed with the same letter are statistically identical $(\mathrm{P}<0.05)$. & \\
& & \\
Table 2. Mean defoliation variation period and range of isohyets. & Mean Range of defoliation \\
\hline Isohyet (mm) & Mean date of defoliation & $\mathbf{( m o n t h s )}$ \\
\hline (months) & $1.41 \pm 1.28 \mathrm{ab}$ \\
900 - 1000 1100 & $2.88 \pm 1.08 \mathrm{a}$ & $1.53 \pm 1.22 \mathrm{ab}$ \\
$800-900$ & $2.82 \pm 2.27 \mathrm{a}$ & $1.55 \pm 1.12 \mathrm{a}$ \\
$700-800$ & $2.81 \pm 1.90 \mathrm{a}$ & $1.40 \pm 1.29 \mathrm{~b}$ \\
$600-700$ & $2.61 \pm 2.05 \mathrm{~b}$ & $1.52 \pm 1.16 \mathrm{bb}$ \\
Average & $2.37 \pm 1.91 \mathrm{~b}$ & $\mathbf{1 . 4 8} \pm 1.21$ \\
\hline
\end{tabular}

Concerning the years, defoliation was spread in 2015 (1.65month) whereas in 2016 (1.38 month) and 2017 (1.42 mois), it was massive. There is a significant difference between years. Duration of defoliation in 2015 was different from what happen in 2016 and 2017 meaning that the range of defoliation was similar between the last two years. However there was a significant difference among years $(0.0000<0.001)$. In other ecologies, some trees conserve their phenological rythm during years. Parfait illustrations are given by Vitex doniana and Sclerocarya birrea which drop their leaves always earlier in Guinean Savannah Highlands (Mapongmetsem, 2005).

Significant interactions were noticed between species - isohyet $(0.000<0.001)$; species - year (0.000<0.001); isohyet - year $(0.000<0.001)$ and species -isohyet-year $(0.0000<0.001)$. For the species-isoyet interaction, the mean period of defoliation starts from March $(2.51 \pm 0.28)$ in $D$. macrocarpum along the isohyet $800-900 m m$ to November $(10.60 \pm 0.65)$ in $V$. doniana along the isoyet $600-700 \mathrm{~mm}$ (Fig.2a). The various species exhibit different attitudes according the rainfall. Hence, D. microcarpum shade off its leaves earlier in the zone while V.doniana does it late. Among the these extremes, exist intermediary species composed of $A$. digitata, Haematostaphis barteri, Hexalobus monopetelatus and Sclerocarya birrea. Concerning the species - year interaction, the mean time of defoliation varies from March 2017 (2.58 \pm $0,22)$ in D. microcarpum to November 2016 $(10.70 \pm 0.55)$ in $V$. doniana (Fig.2b). V.doniana is a species with extended defoliation.

The isohyet -year interaction was equally significant (0.000<0.001). The mean period of defoliation fluctuate from April $(4.20 \pm 2.74)$ in the isohyet 3 in 2017 to June $2016(5.30 \pm 2.33)$ in the isohyet 3 (Fig.3). In the year 2016, defoliation was generally extended along the isoyet 3 and 4 in the area. 


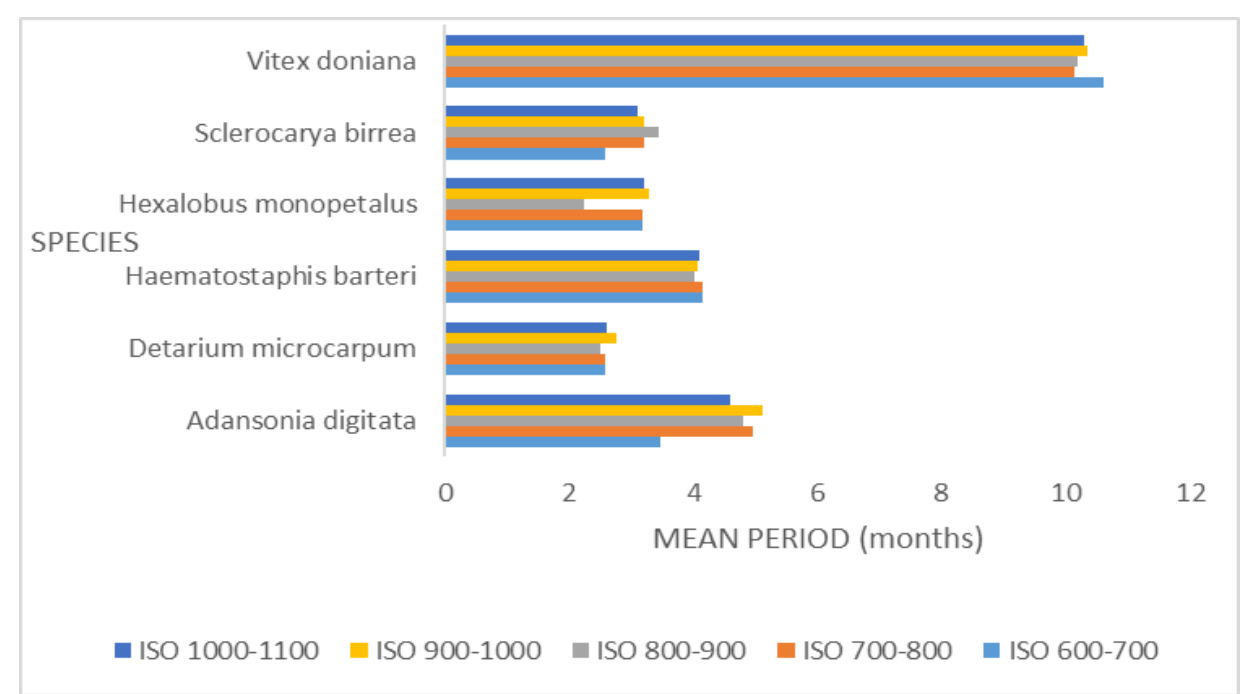

(a)

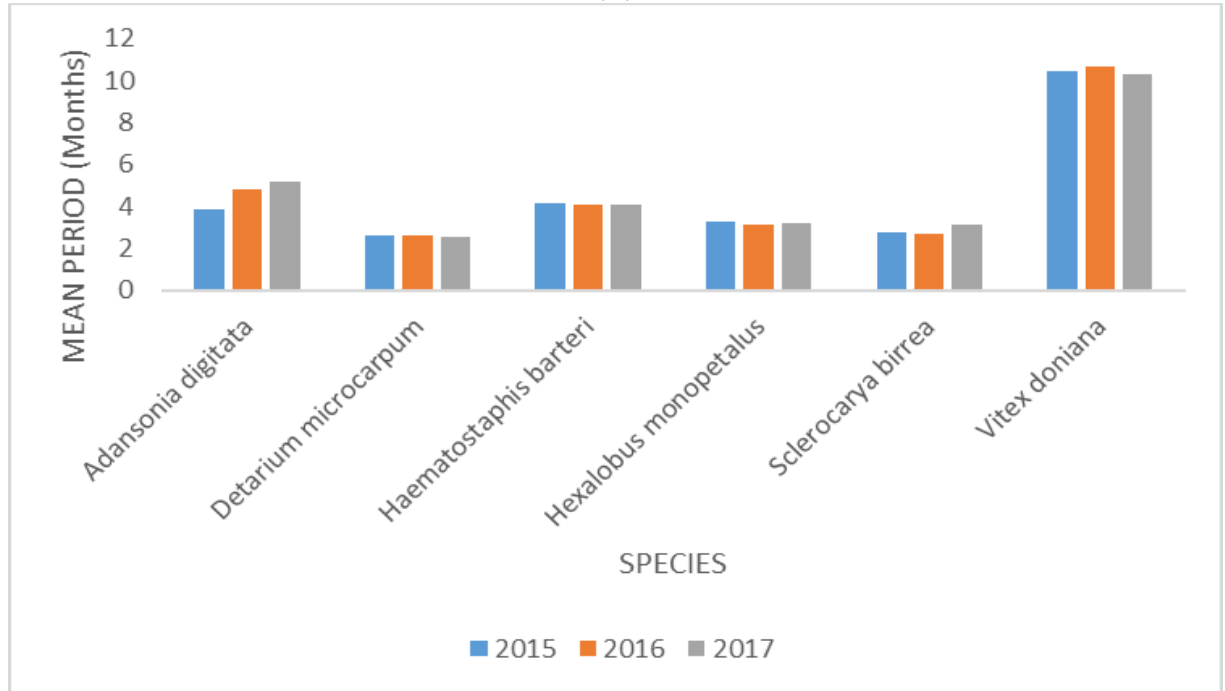

(b)

Fig. 2: Interaction species - isoyet and species-year on mean period of defoliation.

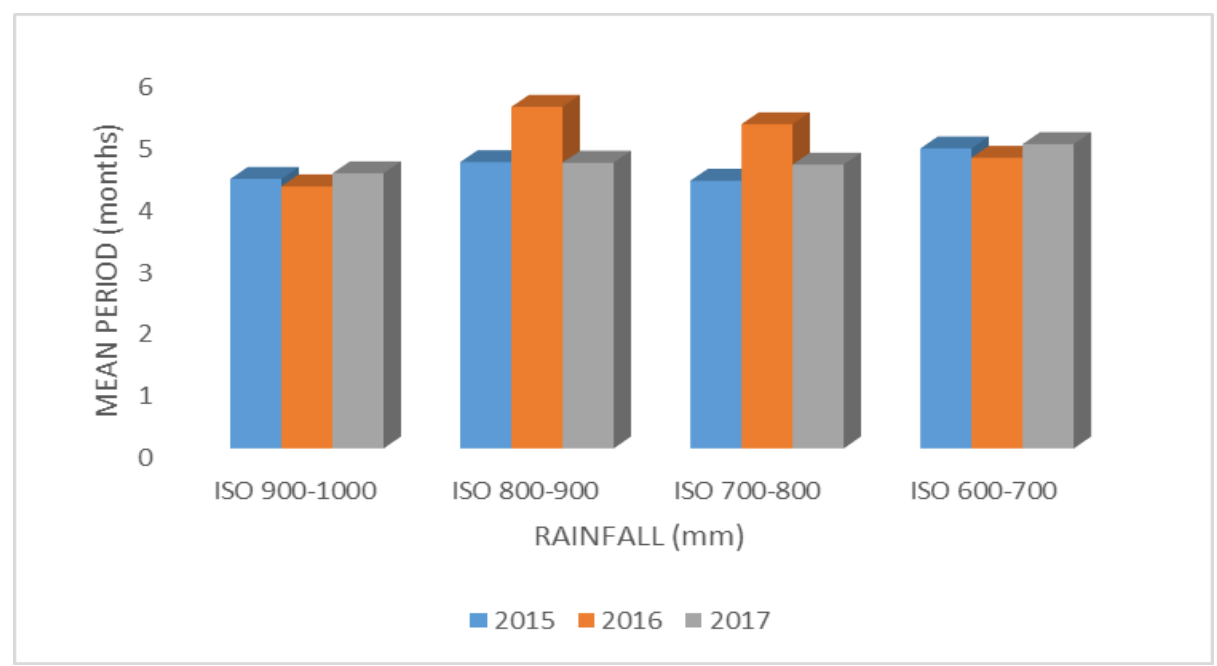

Fig. 3: Interaction isohyet-year on the mean period of defoliation. 
The duration of defoliation in species oscillates from $2.51 \pm 0.28$ in D. macrocarpum and $10.60 \pm$ 0.65 months in Vitex doniana independently to isoyet (Fig. 4a). The duration of 11 months in $V$. doniana confirms the character of extended defoliation above mentionned in the species.
For the species by year interaction, the range of defoliation varies from $2.58 \pm 0.22$ in $D$. microcarpum in 2017 to $10.70 \pm 0.55$ months in $V$. doniana in 2016 (Fig. 4b). D. microcarpum is a species of short defoliation in the contrary of $V$. doniana.

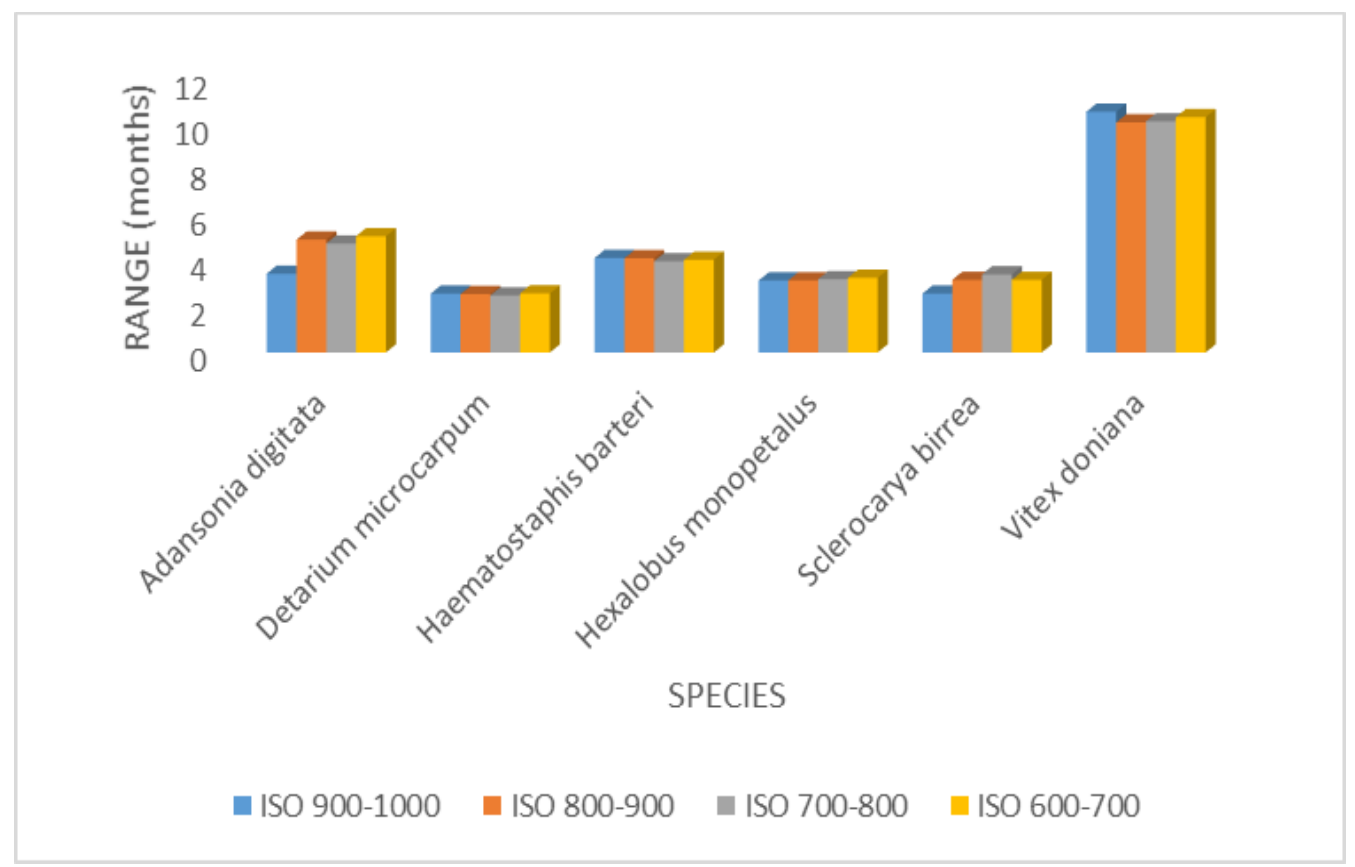

(a)

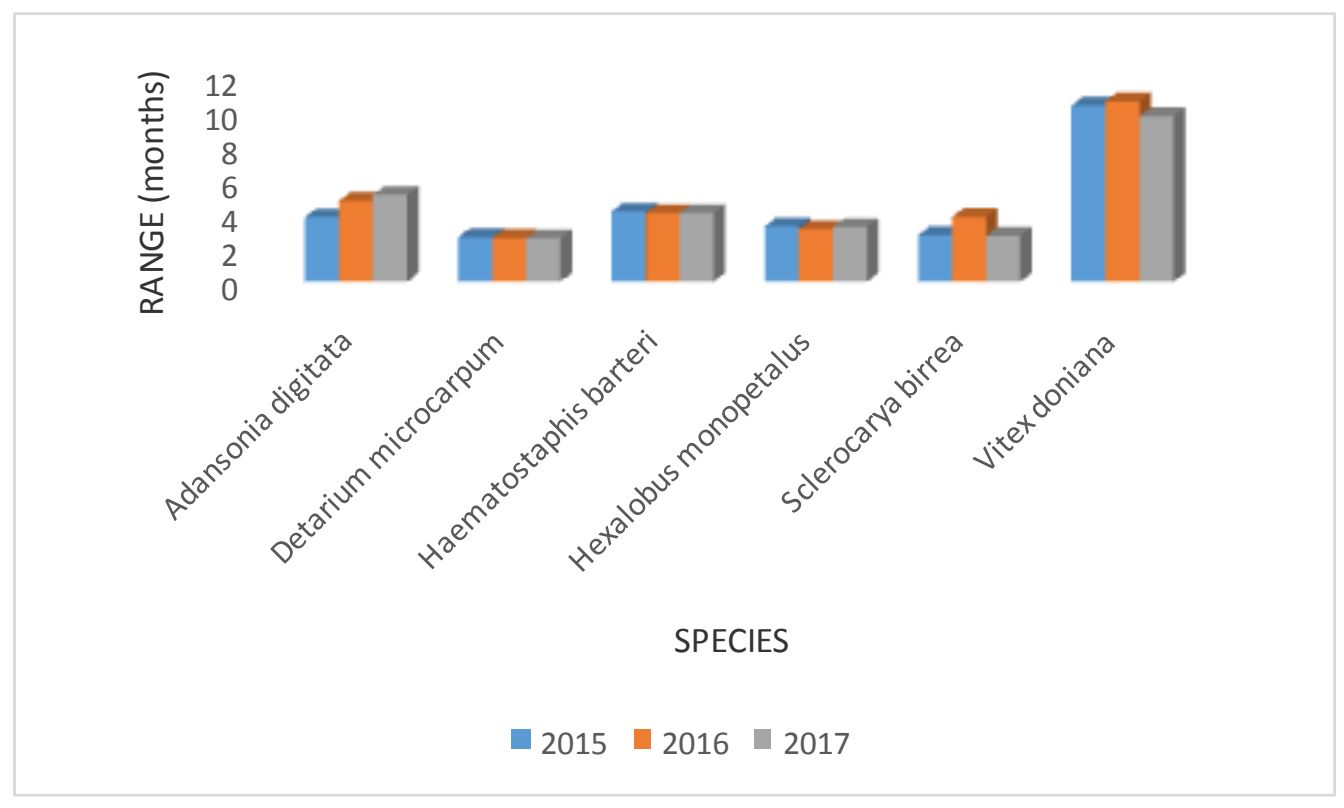

(b)

Fig. 4: Interaction species-isoyet and species-year on range of defoliation.

The examination of the isohyet by year show that the duration of defoliation of the species was exceptional during the year 2016 among the isohyets $3(5.30 \pm 2.33$ months $)$ and $4(5.22 \pm$ 2.46 months). The results are depicted in Fig. 5 . 


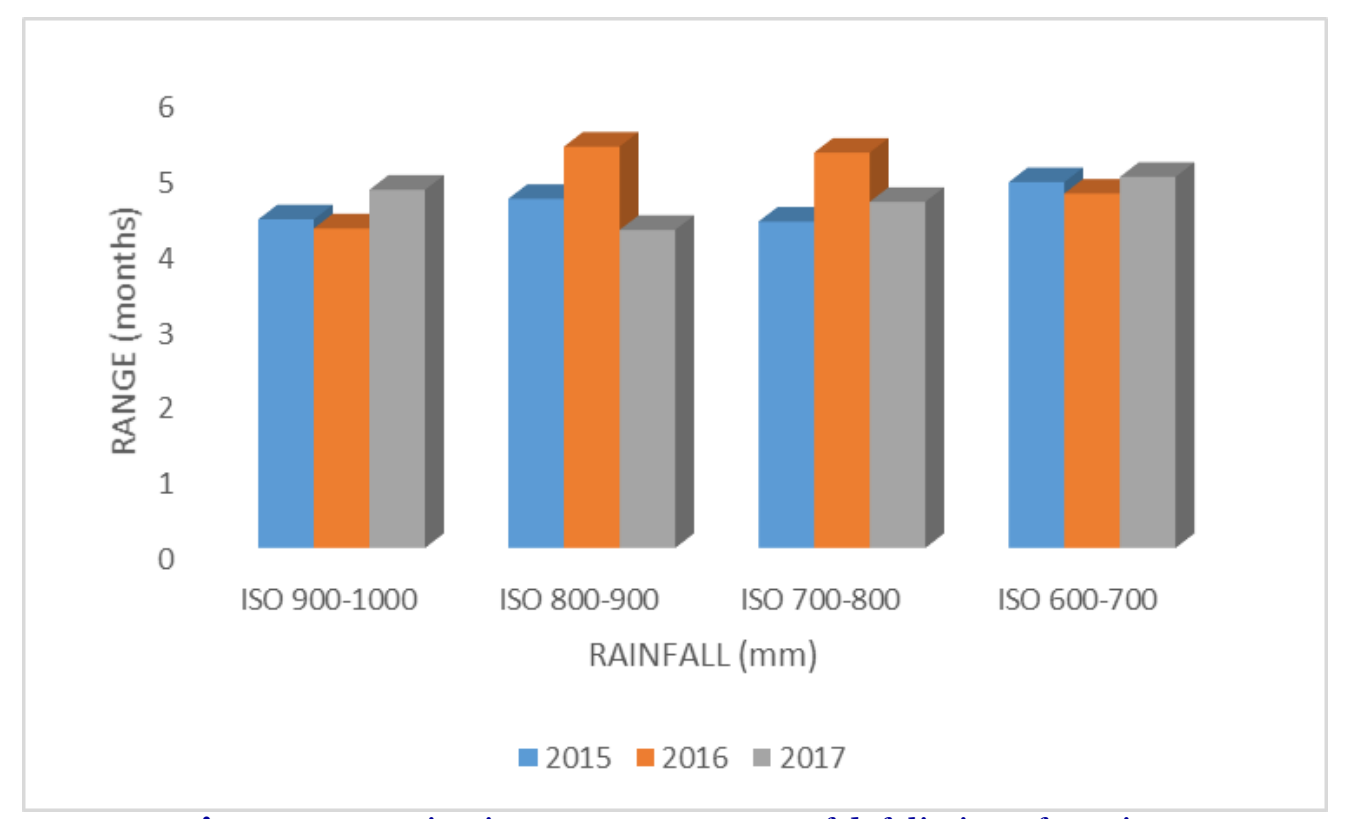

Fig. 5 : Interaction isoyet-year on range of defoliation of species.

In the majority of species, defoliation take place in the dry season. The trifactorial interaction speciesyear-isohyet was significant $(0.0000<0.001)$ suggesting that the behaviour of the various species varies according the years and isohyet as well as the specific characters of each species. Mapongmetsem et al.(1998) report analogous behaviours in forest zone of Cameroon.

Considering the relation between defoliation and environmental, different behaviours can be reported. Leaf fall in $A$. digitata, is slow and inversely correlated to precipitations $(\mathrm{r}=-0.25$; $\mathrm{P}$ $<0.001)$. This findings indicate that in this species, $25 \%$ of trees shade off their leaves durting rainy season while $75 \%$ drop theirs in dry season. For temperature, a low negative correlation was equally observed $(\mathrm{r}=-0.13 ; \mathrm{P}<0.05)$.

Defoliation in D. microcarpum took place in absence of precipitations. $15 \%$ of trees are conversly linked to increase precipitations $(\mathrm{r}=$ $0.15 ; \quad \mathrm{P}<0.05$ ) and positive correlated to temperature $(\mathrm{r}=0.31 ; \mathrm{P}<0.001)$. Leaf fall in $S$. birrea is negatively correlated to precipitations $(\mathrm{r}=$ - 0.21; P < 0.001). Few are trees (21\%) which lose theirs in dry season. Relation between defoliation and temperature is weak and positive $(\mathrm{r}=0.11 ; \mathrm{P}$ $<0.001)$.

Out of the above relations reported, no correlation between defoliation and climatic parameters has been noticed during this work in other species.

\section{Conclusion}

The study has demonstred that defoliation in tropical plant species is complexe and governed by both environmental and endogenous factors. Among the plant species studied, three are evergreen (Balanites aegyptiaca, Diospyros mespiliformis and Tamarindus indica) while six others present total defoliation. All the epecies have an optimum of leaf fall between January and December. Yellowing of leaves appear to be precursor sign of leaf fall. Mean period and range of spread of this phenophasis varies accoding species and pedoclimatic conditions of the station.

To the functional individualism of trees from a species is added that of branches of the same trees. Predicting analysis show that defoliation is a dynamic phenomenon and atypic. Its determinism undergoes exogenous and endogenous influences.The effect of exogenous and endogenous factors vary in fonction species and pedoclimatic conditions of sites. Data presented in the present work were lacking and bring a new or complementary lighting on phenology and defoliation of some tropical trees but their interpretation show that, if it is possible to find average behaviours, individuals factors remain important for precise predictions. 


\section{Conflict of interest statement}

Authors declare that they have no conflict of interest.

\section{Acknowledgement}

The authors wish to express their gratitude to the anonymous reviewers for invaluable comments and inputs on the manuscript. The authors are indebt the Laboratory of biodiversity and Sustainable development, to Research and Application Interface Centre for Sustainable Development in Africa (CIRDA) for its financial support.

\section{References}

Adjanohoun E. J., Assi A. L., Floret J. J., Guinko S., Koumaré M., Ahyi A. M. R. \& Raynal J., 1981. Médecine traditionnelle et pharmacopée. Contribution aux études ethnobotaniques et floristiques au Mali. ACCT. 3ième édition. 291p.

Agbogan A., Tozo K., Walaa K., Bellefontaine R., Dourma M., Akpavia S., Woegana Y.A., Dimobea K. et Akpaganaa K., 2015. Structure des populations de Sclerocarya birrea, Lannea microcarpa et Haematostaphis barteri au nord du Togo. Journal of Animal \& Plant Sciences, 25 (2) : 3871-3886.

Aitken S. N., Yeaman S., Holliday J. A., Wang T. \& Curtis-Mc Lane S., 2008. Adaptation, migration or extirpation : climate change outcomes for tree populations. Evolutionary Applications 1 : 95-111.

Ajenifujah-Solebo S. O. \& Aina J. O., 2011.Physicochemical properties and sensory evaluation of jam made from black-plum fruit (Vitex doniana)African Journal of Food, Agriculture, Nutrition and Development, 11(3): 4772-4784.

Akotegnon R., Michodjehoun L., Behanzin J., Houeze E. and Sezan A., 2018. Impact des extraits éthyliques des feuilles de Hexalobus Monopetalus sur le métabolisme protéique des rats Wistar. International Journal of Multidisciplinary and Current Research. https://www.researchgate.net/publication/32 3029609

Akouegninou A., Burg W.J.V. et Maesen L.J.G.V.,
2006. Flore analytique du Bénin. Brackuyspublishers wagneningen. 1034p.

Ali M., 2000. Les prix des produits et le système productif dans la zone cotonnière de l'ExtrêmeNord du Cameroun. Cahiers Agricultures, 9: 125-130.

Amal A., Muh R.A., Nur Z.L., Uca S., Sukri N., Rosmini M., Erman S. \& Yudistira L., 2018. Production and decomposition rate of litterfall Rhizophora mucronata. EnvironmentAsia, 11 (1) : $112-124$.

Ambé G.-A., 2000. Les fruits sauvages comestibles des savanes guinéennes de Côte d'Ivoire : état de la connaissance par une population locale, les Malinké. Biotechnol.Agron. Soc. Environ. 5 (1), 43-58.

Ambé G.-A., 2005. Les fruits sauvages comestibles des savanes guinéennes de Côte-d'Ivoire : état de la connaissance par une population locale, les Malinké. Biotechnol. Agron. Soc. Environ. 20015 (1), 43-58.

Ana D.S.D.F.., Tácio O.D.S., Rômulo S.C.M., Everardo V.D.S.B.S., Eduado R.A. \& Vânia D.S.F., 2011. Nodulation and nitrogen fixation of caatinga forage species grown in soils of the semi-arid area of Paraiba. Revista Brasileira de Zootecnia, 40 (9) : 1856-1861.

Andersson M., Kjøller A. and Struwe, S., 2004. Microbial enzyme activities in leaf litter, humus and mineral soil layers of European forests. Soil Biology and Biochemistry, 36 (10) : 1527 1537.

Andriaharimalala T., Roger E., Rajeriarison C. \& Ganzhorn J.U., 2012. Analyse structurale des différents types de formation végétale du Parc National d'Andohahela (Madagascar) comme habitat des animaux. Malagazy Nature, $6: 24$ -45 .

Anguessin B., Ibrahima A. and Mapongmetsem P.M., 2017. Litter quality an decomposition along climatic gradient in northern Cameroon. International Journal of Applied Research, 3 (10) : $32-38$.

Anonyme, 2010. Schéma directeur régional d'aménagement et de développement du territoire (SDRDDT) - Région de l'ExtrêmeNord. Version provisoire. $94 \mathrm{p}$.

Antonios P., 2002. Développement durable : Rêve ou réalité. Le Courrier, 193 : 28-29.

Arbonnier M., 2000. Arbres, arbustes et lianes des 
zones sèches d'Afrique de l'Ouest. CIRAD/MNHN/UICN. 539p.

Arbonnier M., 2002. Arbres, Arbustes et Lianes des Zones Sèches d'Afrique de l'Ouest. $2^{\mathrm{ème}} \mathrm{Ed.}$., CIRAD - MNHN, Paris. 573p.

Arous J.L., Alegre L., Ali dib T., Benlarbi M. et Monneveux P., 1991. Epidermal and stomatal conductance in seedlings of durum wheat landraces and varieties. Collogue PhysiologyBreeding of Winter Cereals for Stressed Mediterranean Environments, Montpellier (France), $3-6$ july 1989. Les colllogues $\mathrm{n}^{\circ} 55$. Paris, Inra éditions.

Asase A., Alfred A. Oteng-Yeboah A.A., Odamtten T.G. \& Simmonds S.J.M., 2005. Ethnobotanical study of some Ghanaian anti-malarial plants. Journal of Ethnopharmacology, 99 : 273-279.

Asase A., Kokubun T., Grayer J.R., Kite G., Simmonds S.J.M., Oteng-Yeboah A.A. et Odamtten T.G., 2008. Chemical constituents and antimicrobial activity of medicinal plants from Ghana: Cassia sieberiana, Haematostaphis barteri, Mitragyna inermis, Pseudocedrela kostchyi. Phytotherapy research, 22 (8) : $1013-1016$.

Assogba A. 1984. Quelques enquêtes sur la pharmacopée traditionnelle vétérinaire en République du Bénin. Com. $13^{\text {ème }}$ conférence de la société ouest africaine de pharmacologie, du 23-25février 1984. Cotonou. 22 p.

Assogbadjo A.E., Kakaï R.G, Vodouhê G.F. \& Sinsin B., 2012. Biodiversity and cultural importance of wild edible trees in Benin (West Africa). Third RUFORUM Biennial Meeting 24 - 28 September 2012, Entebbe, Uganda. pp. $631-637$.

Assogbadjo A.E., Kyndt F.T., Chadare J., Sinsin B., Gheysen G., Eyog-Matig O. et Van Damne P., 2009. Genetic fingerprinting using AFLP cannot distinguish traditionnally classsified baobab morphotypes. Agroforest Syt,75 : 157 165 .

Augusto L., 1999. Etude de l'impact de quelques essences forestières sur le fonctionnement biogéochimique de la végétation des sols acides. Thèse de Doctorat, Université de Nancy I. 161p.

Atato A., Wala K., Batawila K., Woegan A.Y. et Akpagana K. 2010. Diversité des fruitiers ligneux spontanés du Togo. Global Science Books, 4 (1): 1-9.
Aube J., 1996. Les Produits Forestiers Non Ligneux. Etude pour favoriser le développement des Produits Forestiers Non Ligneux dans le cadre de CARPE. ForestrySupport Program/ USAID. 120 p.

Aubreville A. 1950. Flore Forestière SoudanoGuinéenne, A.O.F.- Cameroun. A.E.F. 523 p.

Aubreville A., 1959. La flore forestière de la Côte d'Ivoire. Tome 11, III, publication $\mathrm{n}^{\circ} 15 \mathrm{du}$ Centre Technique Forestier Tropical, Nogentsur-Marne, France. 674 p.

Aubréville A., 1968. Les Césalpinioidées de la flore Camerouno-Congolaise. Adansonia, 2(8) : 147175.

Aubréville A., 1970. LégumineusesCésalpinioidées. Flore du Cameroun, Muséum National d'Histoire Naturelle de Paris, France.

Aussenac G., 1969. Production de litière dans divers peuplements de l'Est de la France.œcol. Plant. Gauthier-Villars IV. pp. 225-236.

Azoulaye G., 1999. Sécurité alimentaire à l'horizon 2010. In : Biotechnologies, amélioration des plantes et sécurité alimentaire. pp. 3-12.

Bâ A.M., Plenchette C., Danthu P., Duponnois R. and Guissou T., 2000.Functional compatibily of two arbuscular mycorhizae with thirteen fruit trees in Senegal. Agrofor.Syt., 50:95 105.

Badolo M., 2004.Défi du changement climatique au Sahel : intégrer la science et le savoir traditionnel pour bâtir des stratégies d'adaptation pertinentes Actes du colloque du projet " appui aux capacités d'adaptation au changement climatique au Sahel ». pp. 23-28.

Badou B.R., Yedomonhan H., Adomou C.A. et Akoegninou A., 2017. Phénologie florale et production fruitière de Syzygium guineense (Willd.) DC. subsp. macrocarpum (Myrtaceae) en zone soudano-guinéenne au Bénin. Int. J. Biol. Chem. Sci., 11(5): 2466-2480.

Baillaud L., 1958. Rythmes endogènes et rythmes exogènes, notamment chez les végétaux. Annales de Biologie 34 (7-8): 299-329.

Baliuckas V., Lagerstrom T., Norell L. \& Erksson G., 2005. Genetic variation among and within Populations in Swedish species of Sorbus aucuparia L. and Prunus padus L. assessed in a nursery trial. Silvae Genetica $54: 1$ - 8.

Bamba K., 1985. Systèmes aériens et racinaires de quelques essences spontanées et exotiques 
dans la région de Saponé. Mém.de fin d'études. Institut Supérieur Polytechnique, Université de Ouagadougou, 135 p.

Barbault B., 2000. Ecologie générale : Structure et fonctionnement de la biosphère. $5^{\text {è }}$ édition, Dunod, Paris. 326p.

Bastide B. et Ouédraogo S.J., 2009. Feux précoces et production fruitière de Detarium microcarpum Guill. et Perr. en zone sud soudanienne du Burkina Faso. Sécheresse, 20 (1) : 11-19.

Bationo B. A., Ouedraogo S. T. \& Guinko S., 2001.Longévité des graines et contraintes à la suivie des plantules d'Afzelia africana SM. Dans une savane boisée du Burkina Faso. ANN. SCI for 69-75.

Bationo B.A., Lamien N., Demers N. et Kandji S., 2009. Culture du baobab; Adansonia digitata L. (Bombacaceae) en planche maraîchère : une méthode pour simplifier sa récolte et favoriser sa propagation au Sahel. Bois et Forêts des Tropiques 299 (1) : 79 - 86.

Batonio A.,2004. Managing nutrient cycles to sustain soil fertility in subsaharan Africa. TSBF/CIAT/Rockfeller Foundation/ (Relma) (Regional land Management Unit). pp 127-136.

Baum D.A., Small R.L. and Wendel J.F., 1998. Biogeography and Floral Evolution of Baobabs (Adansonia, Bombacaceae) as Inferred fFrom Multipl Data Sets. Syst. Biol. 47 (2) : 181 - 207.

Baumer M., 1987. Le rôle possible de l'agroforesterie dans la lutte contre la désertification et la dégradation de l'environnement. CTA, Pays-Bas. 262 p.

Baumer M., 1990. Agroforesterie pour les zones sèches Africaines. Bois et forêts des tropique $\mathrm{n}^{\circ} 225$, pp 55- 64 .

Becker M., 1981. La phénologie des hêtraies. Le hêtre, INRA Ed., 108-117.

Belesi K.D.K.K., 2009. Inventaire et description des fabaceae arbres (momosoidae et faboidae) de Kinshasa et ses environs. https://www.memoireonline.com/02/12/5298 /m-inventaire-et-description-des-fabaceaearbres-momosoidae-et-faboidae--de-Kinshasaet-ses-environs1-html

Bellakhdar J., 1997. La Pharmacopée marocaine traditionnelle - Ibis Press. pp.489-491.

Bellefontaine R., Petit S, Pain O.M., Deleport P. \& Bertault J.G., 2001. Les arbres hors forêt vers une meilleure prise en compte. FAO conservation 35, Rome. 231p.

Berg B.\& Mc Claugherty C., 2008. Plant litter. Decomposition, humus formation, carbon sequestration. $2^{\text {nd }}$ édition. Sprinter, Finland. $338 \mathrm{p}$.

Bergeret A. et Ribot J.C., 1990. L'arbre nourricier en pays sahélien. Ministère de la Coopération et du Développement et Fondation de la maison des sciences de l'homme. Paris. 237p.

Berhaut J., 1975. Flore Illustrée du Sénégal Ficoïdées à Légumineuses. Tome IV. Gouvernement du Sénégal, Ministère de la Protection de la Nature, Ministère du Développement Rural, Direction des Eaux, Dakar. pp. 375-382.

Berka S. et Aïd F., 2009. Réponses physiologiques des plants d'Argania spinosa (L.) Skeels soumis a` un déficit hydrique édaphique. Sécheresse 20 (3) : 296-302.

Bernhard F., 1970. Etude de la litière et de sa contribution au cycle des éléments minéraux en forêt ombrophile de Côte d'Ivoire. Oecol.Plant., 5 : 247-266.

Bertrand A., Babin D., Nasi R. 1999. Les composantes de l'aménagement forestier et leur incidence financière. Bois et Forêts des Tropiques. 1(261) : 51-59.

Betlem J., 1988. Etude de phénologie des arbres dans la Moyenne Vallée du fleuve Sénégal. Projet bois de villages et reconstitution des forêts classées de Gonakie dans la Moyenne Vallée du fleuve Sénégal. Note technique $n^{\circ} 6$. 45p.

Betti J.L, 2002. Medicinal plants sold in Yaounde markets, Cameroon. African Study Monographs 23 (3) : 47-64.

Biau S.S.H., Moutouama J.K., Dan B.S.C., Amahowé O.I., Moutouama T.F. and Natta K.A., 2017. Uses of Haematostaphis barteri Hook.f. among the Waaba and Bètammaribè in North-Benin and impact on the species vulnerability. International Journal of Biodiversity and Conservation, 9 (5) : 146 157.

Bibani R.M., Jonkers W.B.J. \& Essama E.J., 2000.Phénologie de 86 essences productrices de bois d'œuvre de la forêt dense humide sempervirente du Sud-Cameroun. Résultats préliminaire. Séminaire FORAFRI de Libreville. Session 2: Connaissance de 
l'écosystème. $16 \mathrm{p}$.

Bikoué C. M. A. \& Essomba H., 2007.Gestion ressources naturelles fournissant les Produits forestiers non ligneux en Afrique Centrale, Projet GCP/RAF/398/GER, Programme Produits Forestier Non Ligneux, No.5., Département Forêt, Rome, FAO. 83p.

Billington H. L. \& Pelham J., 1991.Geneticvariation in the date of budburst in Scottish birch populations - implications for climate change. Functional Ecology5 : 403 - 409.

Bindzi M.M.-A., Lacoste A., Akoa A. et Biye H.E., 2005. Phénologie florale dans une jeune forêt secondaire hygrophile du Cameroun.Acta Botanica Gallica, 152 (1) : 25 - 43.

Bloc D. \& Gouet J.P., 1977. Influence des sommes de températures sur la floraison et la maturité du Maïs.

Bonkoungou G.E., 1987.Monographie du néréParkia biglobosa (Jacq Benth), espèce agroforestière à usages multiples. IRBET/CNRST, Ouagadougou, Burkina Faso. $69 \mathrm{p}$.

Bonnefoy C., 2013.Observation et modélisation spatiale de la température dans les terroirs viticoles du Val de Loire dans le contexte du changement climatique. Géographie. Université Rennes 2. 322p.

Borchert Q., 1973. Simulation of rhythmic tree growth under constant conditions : Plant Physiology 29 : 1973-1980.

Borchert R., Robertson K., Schwartz M.D., Williams-Linera G., 2005. Phenology of temperate trees in tropical climates. International Journal of Biometeorology, 50 : 57-65.

Bourou S., Ndiaye F., Diouf M., Van Damme P., 2011. Effets de l'inoculation mycorhizienne sur le comportement agro-physiologique des écotypes du tamarinier (Tamarindus indica L.) au Sénégal. Journal of Applied Biosciences, 46 : 3093-3102.

Bourou S., 2012. Étude éco-physiologique du tamarinier (Tamarindus indica L.) en milieu tropical aride,

Boussim I.J., Sallé G. et Guinko S., 1993.Tapinanthus parasite du karité au Burkina Faso. Bois et Forêts des Tropiques, $238: 53-65$.

Bowe C., 2007. Predicting suitable areas for the production of tamarind (Tamarindus indica L.) an underutilised fruit tree species, $P h D$ Thesis, University of Southampton, Southampton, UK. 230 p.

Boyer J., 1972. Evolution saisonnière de la production de litière et de la décomposition des feuilles dans une cacaoyère camerounaise. $4^{\text {ème }}$ conférence Internationale sur les Recherches Cacaoyères. St Augustine (Trimidad), 8-18 janvier 1972. pp. 226-234.

Breman H. \& Kessler J.- J., 1995. Woody plants in agro-ecosystems of semi-arid regions with emphasis on the sahelian countries. Advanced series in agricultural sciences 23. Paris. Springer-Verlag. $340 \mathrm{p}$.

Brown M. S., 1984. Mangrove litter production and dynamics. Division of Biology and Living Resources.University of Miami. pp. 231-238.

Cannell M.G.R. \& Smith, R.I., 1986. Climatic warming, spring budburst and frost damage on trees. Journal of Applied Ecology, $23:$ 177-191.

Cannell M.G.R., 1989. Chilling, thermal time and the date of flowering of trees. In : Manipulation of fruiting. Wright, C.J. (ed). Butterworths, London. pp. 99-113.

Catayud P.-A., Garrec J.-P. et Nicole M., 2013. Chapitre 14 : Adaptation des plantes aux stress environnementaux. In : Interactions insectes plantes. Sauvion N., Catayud P.-A., Thiéry \& Marion-Poll (Eds). pp. 229-245.

Chambers J., 2001.Pinus monophylla establishment in an expanding Pinus Juniperus woodland : environmental conditions, facilitation and interacting factors. J. Veg.Sci., 12 (1) : 27-40.

Chandrasekharan C., 1995. Terminology, definition and classification of products other than wood. In : Report of international expert consultation on non-wood forests products $\mathrm{n}^{\circ} 3, \mathrm{FAO}$, Rome. pp. 345-380.

Chapman C.A., Wrangham R.W., Chapman L.J., Kennard D.K. \& Zann A.E., 1999.Fruit and flower phenology at two sites in Kibale National Park, Uganda. Journal of Tropical Ecology, 15: 189 - 211.

Chave J., Navarrette D., Almeida S., Alvarez E., Aragão L.E.O.C., Bonal D., Chãtelet P., SilvaEspejo J.E., Goret J.Y., Von Hildebrand P., Jiménez E., Patiňo S., Peňuela M.C., Philips O.L., Stevenson P. and Malhi Y., 2010. Regional and seasonal patterns of litterfall in tropical South 
America. Biogeosciences, $7: 45-55$.

Chen H.Y.H., Brant N.A., Seedre M., Brassard W.B. and Taylor R.A., 2017.The contribution of litterfall to net primary production during secondary succession in the boreal forest. Ecosystems, 20 (4) : $830-844$.

Chevallier M.H., Bensaid S., Diallo O.B., Sahki R., Ganaba S., Sanou J., Bouguedoura N., Vaillant A. et Babin D., 2003. Biodiversité et multiplidisciplinarité : méthodologie pour les zones arides. Bois et forêts des tropiques 276 (2) : $33-41$.

Childes S.L., 1988. Phenology of nine common woody species in semi-arid, deciduous Kalahari sand vegetation. Vegetatio, 79 (3) : 151-163.

Chuine I., K. Kramer K. and Hanninen H., 2003.Plant development models. Phenology : an Integrative Environmental Science39 : 217235 .

Chylarecki H. \& Straus H., 1968. Results of phenological observations in the years 19531962 on trees and shrubs of foreign origin cultivated in the Komik Arboretum. Arboretum Kornikie, $13:$ 30-142.

CIFOR, 2003 .Forêts et populations : vers une recherche qui fait une différence. Bongor, Indonésie. $90 \mathrm{p}$.

Comps B., Letouzey J. \& Savoie J.-M., 1987. Phénologie du couvert arborescent dans une chênaie-hêtraie d'Aquitaine. Ann. Sci. For. 44 : 153-170.

Criquet S., Tagger S., Vogt G. et Le Petit J., 2002. Endoglucanase and $\beta$-glycosidase activities in an evergreen oak litter : annual variation and regulating factors. Soil Biology and Biochemistry, 34 (8) : 1111-1120.

Cronquist A., 1988. The Evolution and classification of flowering plants. Allen Press. Lawrence, Kansas. 555 p.

Cuevas E., Brown S., \& Lugo A.E., 1991. Above and belowground organic matter storage and production in a tropical pine plantation and a paired broadleaf secondary forest. Plant and Soil, 135, 257-268.

Cuny P., Sanogo S. \& Sommer N., 1997. Arbres du domaine soudanien. Leurs usages et leur multiplication. IER/Programme Ressources Forestières. IC Suisse. Mali. 47-50.

D'Annunzio R., 2008. Dynamics of organic matter eucalyptus clonal plantations in Congo. Life
Science. Agro Paris Tech. 222p.

Damba A., 2007. PFNL et leur durabilité dans le Mayo-Louti (Nord, Cameroun). Mémoire de Maîtrise, Université de Ngaoundéré, Cameroun. 61p.

Davis M. B. \& Shaw R. G., 2001. Range shifts and adaptive responses to Quaternary climate change. Science 292 :673-679.

De Bie S., Ketner P.M., Geerling M., 1998. Woody plant phenology in the West Africa savanna. $J$ Biogeogr, $25: 883-900$.

De Jong W., Campbell B.M. \& Schröder J.M., 2000.Substaining incomes from non timber forest products : introduction and synthesis. International Tree Crops Journal,10 (4) : 267275.

Défila C. \& Clot B., 2000. Tendances révélées par l'étude phénologique des arbres en Suisse. Quelle sylviculture pour les climats à venir ? Actes de la Journée thématique de L'Antenne romande du WSL du 28 novembre 2000 à VEP F-Lausanne. Martine Rebetez et Jean Combe (éds).

Delpech, R., Dumé, G., Galmiche, P., 1985. Typologie des stations forestières. Vocabulaire. Ministère de l'Agriculture. Direction des Forêts. Institut pour le Développement Forestier. 243p.

Devineau J.-L., 1982. Etude pondérale des litières d'arbres dans deux types de forêts tropophiles en Côte d'Ivoire. Annales de l'Université d'Abidjan série E (écologie), 15 : 27 - 62.

Devineau J.-L., 1999. Seasonal rhythms and phenological plasticity of savanna woody species in a fallow farming system (southwest Burkina Faso). J. Top. Ecol., 15 : 497-513.

Dghim F., Abdellaoui R., Boukhris M., Neffati M., Chaieb M., 2018. Physiological and biochemical changes in Periploca angustifolia plants under withholding irrigation and rewatering conditions. South African Journal of Botany, 114 : 241-249.

Diallo B, Mckey D., Chevallier M.-H., Joly H., \& Hossaert-Mckey M., 2008. Breeding system and pollination biology of the semidomesticated fruit tree, Tamarindus indica L, (Leguminosae : Caesalpinioideae): Implications for fruit production, selective breeding, and conservation of genetic resources, African Journal of Biotechnology, 7: 4068-4075. 
Diallo B.O., 2001. Biologie de la reproduction et évaluation de la diversité génétique chez une légumineuse : Tamarindus indica L. (Caesalpinioideae). Thèse Université Montpellier II. Science etTechnique du Languedoc. $119 \mathrm{p}$.

Diallo M. D., Mahamat-Saleh M., Ndiaye O., Diop A. \& Guisse A., 2015a. Influence de la décomposition de la nécro-masse des espèces végétales tropicales sur le $\mathrm{pH}$ et la structure génétique des communautés bactériennes d'un sol ferrugineux tropical au Sénégal. Journal of Applied Biosciences, 91 (1) : 8547-8558.

Diallo M.D., Ndiaye O., Diallo A., Sakh M.M., Bassene C., Wood S.A., Diop A. et Guissé A., 2015b. Influence de la litière foliaire de cinq espèces végétales tropicales sur la diversité floristique des herbacées dans la zone du Ferlo (Sénégal). J. Biol. Chem. Sci.,9 (2) : 803 - 814.

Diallo M.D., Mahamat-Saleh M., Diallo A., Bassene C., Ndiaye O., Niang K., Diop A. et Guisse A., 2016a. Caractérisation de la variabilité des phénophases de cinq espèces végétales sahéliennes dans la zone Nord Ferlo, Sénégal. Rev.Ivoir.Sci.Technol., 27 : 117-135.

Diallo M.D., Mahamat-Saleh M., Goalbaye T., Diop L., Wade T.I., Niang K. \& Guisse A., 2016b. Chute et décomposition de la litière de cinq espèces ligneuses et leur influence sur la biomasse herbacée dans la zone Nord Ferlo du Sénégal. J. Rech.Sci, Univ. Lomé (Togo), 18 (3) : $1-18$.

Diarra N., Togola A., Denou A., Willcox M., Daou C. et Diallo D., 2016. Etude ethnobotanique des plantes alimentaires utilisées en période de soudure dans les régions Sud du Mali. Int. J. Biol. Chem. Sci., 10(1) : 184-197

Differt J., 2001. Phénologie des espèces arborées. Synthèse bibliographique - Analyse des données du Réseau National de Suivi à long terme des Ecosystèmes Forestiers (RENECOFOR). 97p.

Diop G.A., Sakho M., Dornier M., Cissé M., Reynes M., 2006. Le baobab africain (Adansonia digitata L.) : principales caractéristiques et utilisations. Fruits, vol. 61 (1) : $55-69$.

Donfack P., Seiny Boukar L. \& M'Biandoun M. 1997. Les caractéristiques du milieu physique. In : Seiny Boukar L., Poulain J-F. \& Faure G. (eds), Agricultures des savanes du NordCameroun : vers un développement solidaire des savanes d'Afrique Centrale. Actes de l'Atelier d'échange, 25-29 novembre 1996, Garoua, Cameroun.Montpellier, France, CIRAD-CD. 528p.

Dosba F. \& Saunier R., 1998. La caractérisation variétale fruitière en France. C.R. Acad. Agric. Fr. 1-236.

Dupriez H. et De Leener P., 1993. Arbres et agricultures multiétagés d'Afrique. Coédition. Terres et vie. CTA. Gembloux. 280 p.

Durand R., 1967. Action de la température et du rayonnement sur la croissance. Annales de Physiologie

Dykstra D.P., Kowero S.G., Ofosu-Asiedu A. \& Kio P., 1996. Chapitre 4: Biodiversité et conservation des Produits Forestiers autres que le bois. In: Promotion de l'aménagement forestier dans la zone de forêt tropicale humide d'Afrique occidentale et centrale anglophone. Rapport final d'un projet de recherche entre le PNUE et le CIFOR. CIFOR (éd), Jakarta, Indonésie. pp. 51-66.

El-Kamali H.H., 2011. Diospyros mespiliformis Hochst. Ex A.D.C. [Internet] Fiche de PROTA4U. Lemmens R.H.M.J., Louppe D. \& Oteng-Amoako A.A. (Eds). PROTA (Plant resources of Tropical Africa / Ressources végétales de l'Afrique tropicale), Wageningen, Pays Bas. http://www.prota4u.org/search.asp. Visité le 7 novembre 2018.

El-Siddig K., Gunasena H., Prasad B., Pushpakumara D., Ramana K., Vijayand P. \& Williams J., 2006. Tamarind (Tamarindus indica L.), British Library, Southampt., Southampton Centre forUnderutilised Crops, UK. $210 \mathrm{p}$.

Fétéké F., Fayolle A., Danou K., Bourland N., Dié A., Lejeune Ph., Doucet J.-L.\& Beeckman H.,2016. Variations saisonnières de la croissance diamétrique et des phénologies foliaire et reproductive de trois espèces ligneuses commerciales d'Afrique central. Bois et Forêts des Tropiques, 330 (4): 3-21.

Kouyaté A.M., 2005. Aspects ethnobotaniques et étude de la variabilité morphologique, biochimique et phénologique de Detarium microcarpum Guill. Et Perr. au Mali. PhD Thesis. Université de Gand, Belgique.

Kramer K., Leinonen I. \& Loustau, D., 2000. The importance of phenology for the evaluation of impact of climate change on growth of boreal, 
temperate and Mediterranean forests ecosystems : an overview.

Lebel F., Debailleul G., Samba S. A. N. \& Olivier A., 2002. La contribution des Produits Forestiers Non-Ligneux à l'économie des ménages de la région de Thiès au Sénégal. $2^{\mathrm{e}}$ Atelier régional sur les aspects socio-économiques de l'agroforesterie au Sahel, Bamako, 4-6 mars 2002. $9 \mathrm{p}$.

Loustau D., Bosc A., Colin A., Davi H., François C., Dufrêne E., Déqué M., Cloppet E., Arrouays D., Le Bas C., Saby N., Pignard G., Hamza N., Granier A., Breda N., Ciais P., Viovy N., Ogée J. \& Delage J., 2005. Modelling the climate change effects on the potential production of French plains forests at the sub regional level. Tree Physiology, 25 : 813 - 823.

Mapongmetsem P. M., 2005. Phénologie et apport $\mathrm{du}$ sol des substances biogènes foliaires de quelques fruitiers sauvages des savanes soudano-guinéennes. Thèse de Doctorat d'Etat, Université de Yaoundé I. 268 p.

Mapongmetsem P. M., Duguma B., Nkongmeneck B. A. et Puig H., 1998. Déterminisme de la défeuillaison chez quelques essences tropicales. Rev. Ecol. (Terre et vie). 53 (3): 193-210.

Mapongmetsem P.M., Duguma B. \& Nkongmeneck B.A., 1999. Domestication of Ricinodendron heudelotii (Baill.) Pierre Ex. Pax. In the humid lowlands of Cameroon. Ghana J.Sci, 38: 3-8.

Mapongmetsem P. M., Djeumene P., Sonna D. \& Doung F., 2008. Utilisation et commercialisation des Produits Forestiers Non Ligneux dans les savanes soudano-guinéennes. Symposium international sur les changements climatiques. Lilongwé, Malawi. 15 p.

Mapongmetsem P. M., Tchingsabé O., Keumezé V. \& Damba A., 2010. Usages et commercialization des Produits Forestiers Non Ligneux dans les savanes soudaniennes. Symposium International de l'Association pour l'Etude de la Taxonomie de la Flore de l'Afrique Tropicale (AETFAT). Antananarivo, Madagascar. 18p.

Mapongmetsem P. M., Nduryang J.B.N., Fawa G. et Dona A., 2015. Contribution à la connaissance des Produits forestiers non ligneux de la zone soudano-sahélienne du Cameroun. Actes du Colloque International : «Biodiversité et changements globaux : valorisation des effluents des industries, des résidus agro-pastoraux et forestiers ». Du 21 au 23 juillet 2015. Université de Ngaoundéré, Cameroun. pp. $139-147$.

Mbarga B.R., Jonkers W.B.J. \& Etoudi E.J., 2003. Phénologie de 86 essences productrices de bois d'œuvre de la forêt dense humide sempervirente du Sud-Cameoun - Résultats préliminaires. Séminaire FORAFRI de Libreville - Session 2 : connaissance de l'écosystème. $16 \mathrm{p}$.

Mbaye T., Ndiaye A., Ngom D., Cissé M. et Gning F., 2014. Facteurs déterminants de la fructification des parcs à baobab (Adansonia digitata L.) en Moyenne et Haute Casamance. Journal of Animal \& Plant Sciences, 22 (2) : $3446-3454$.

M'biandoun M., Guibert H. \& Olina J.P., 2003.Caractérisation du climat dans quatre terroirs de la zone soudano-sahélienne au Nord-Cameroun et conséquences pour l'agriculture. In: Savanes africaines : des espaces en mutation, des acteurs face à de nouveaux défis. Jamin J.Y., Seiny Boukar L., Floret C. (éds). Actes du colloque, mai 2002, Garoua, Cameroun.Prasac, N’Djamena, Tchad Cirad, Montpellier, France.

Menga P., Bayol N., Nasi R. et Fayolle A., 2012. Phénologie et diamètre de fructification du wengé, Millettia laurentii De Wild. : Implications pour la gestion. Bois et Forêts des Tropiques, 312 (2) : 31-41.

Newberry D. M., Chuyong G. B., Zimmermann L., 2006. Mast fruiting of large ectomycorrhizal African rain forest trees: importance of dry season intensity, and the resource limitation hypothesis. New Phytologist, 170: 561-579.

Puig H. \& Delobelle J.L., 1988. Production de la litière, nécromasse, apports minéraux au sol par la litière en forêt guyanaise. Rev. Ecol. (Terre Vie), $43: 3$-22.

Ouedraogo A., Thiombiano A. et Ginko S., 2004. Utilisation, état des peuplements et régénération de cinq espèces ligneuses utilitaires dans l'Est du Burkina Faso, Atelier de Fada N'Gourma. pp. 173-181.

Ouedraogo M., 1987. Note d'information sur le papillon du karité: Cirina butyrospermii. Recueil des communications présentées au séminaire national sur les essences forestières locales, 6-10 juillet 1987, Ouagadougou, Burkina Faso, IRBET/CILSS. pp 130-133. 
Singh S., Parasharami V. and Rai S., 2013. Medicinal uses of Adansonia digitata L. : An endangered tree species. Journal of Pharmaceutical and Scientific Innovation, 2 (3) : $14-16$.

Rasamimanana N., Ratsirarson J. \& Richard A.F., 2012. Influence de la variabilité climatique sur la phénologie de la forêt de la Réserve Spéciale de Bezà Mahafaly. Magalasy Nature, 6: 67 82.

Tchiegang-Megueni C., Mapongmetsem P. M., Akagou Z. H. C. et Kapseu C., 2001. An ethnobotany survey of the fruit trees in the northern Cameroon. Forests, Trees and Livelihoods, 11: 149-158.

Tchingsabé O., 2007. Produits Forestiers Non Ligneux et qualité dans le Mayo-Rey (Nord, Cameroun). Mémoire de Maîtrise, Université de Ngaoundéré, Cameroun. 59 p.

Traoré M., 2000. Etude de la phénologie, de la régénération naturelle et des usages de Piliostigma reticulatum D.C. Hochst en zone nord soudanienne du Burkina Faso. Mémoire d’ingénieur de développement rural. 76p.

\section{How to cite this article:}

Nduryang J. B. N., Hamawa, Y., Baye-Niwah, C., Tsobou, R., Fawa, G., Mapongmetsem, P. M., 2019. Determinism of shade off in tropical species of the Sudano - Sahelian zone of Cameroon. Int. J. Curr. Res. Biosci. Plant Biol. 6(2), 11-28. doi: https://doi.org/10.20546/ijcrbp.2019.602.002 